
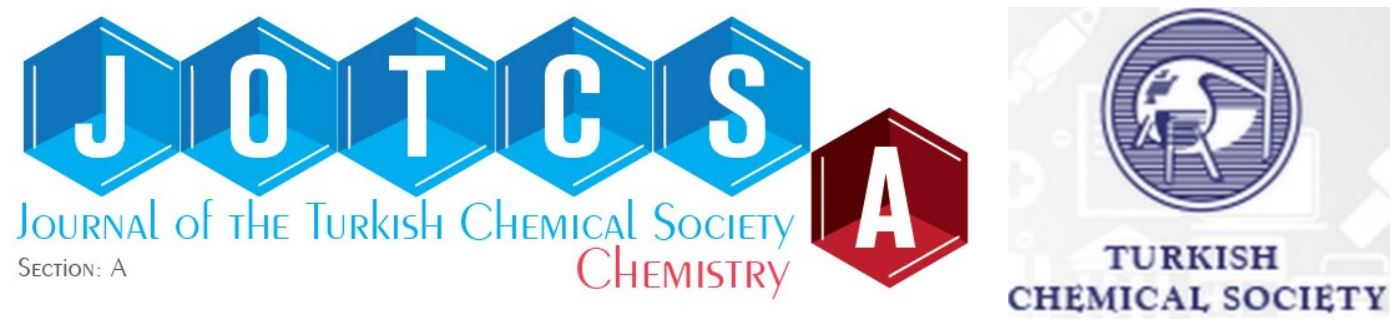

\title{
Ultrasonic-Assisted Removal of Eriochrome Black T onto Vermicompost: Characterization, Isotherm and Kinetic Modelling
}

\author{
Zeynep Ciğeroğlu ${ }^{1}$ iD), Eyüp Yildirir ${ }^{1 *}$ (D) \\ ${ }^{1}$ University of Uşak, Department of Chemical Engineering, Uşak, 64000, Turkey
}

\begin{abstract}
Recently, utilization of biological adsorbents plays an important role in the removal of toxic dyes such as Eriochrome Black T (EBT) azo-dye as they are considered as being produced from natural renewable source, easy availability, low cost, and being environmentally friendly. In this study, vermicompost (VC) was utilized to remove Eriochrome Black T (EBT) azo-dye from aqueous solution along ultrasonic ultrasonic-assisted adsorption. The parameters such as $\mathrm{pH}$, adsorbent amount, operating time, and initial EBT concentration were investigated. The highest adsorption capacity was obtained as 50.64 $\left(\mathrm{mg}-\mathrm{EBT} \mathrm{g}^{-1}-\mathrm{VC}\right)$ at the $\mathrm{pH}$ of value of 2 after 2 minutes of ultrasonic adsorption. Pseudo first order kinetic model fitted very well with the experimental data $\left(R^{2}=0.9824\right)$. The determination coefficient of Temkin isotherm model $\left(R^{2}=0.8659\right)$ revealed that suggested model was compatible to experimental results. The results suggested that ultrasonic assisted adsorption of EBT onto VC could be cost- and time-efficient. Besides, the Scanning Electron Microscopy (SEM) analysis of adsorbent identified the surface structure morphology of VC. Moreover, functional groups of VC were detected after and before the ultrasonicassisted adsorption by using Fourier Transform Infrared Spectroscopy (FTIR). Thus, interaction mechanism between VC and EBT were determined.
\end{abstract}

Keywords: Ultrasonic assisted adsorption, vermicompost, Eriochrome Black T

Submitted: September 21, 2021. Accepted: November 10, 2021.

Cite this: Ciğeroğlu Z, Yildirir E. Ultrasonic-Assisted Removal of Eriochrome Black T onto Vermicompost: Characterization, Isotherm and Kinetic Modelling. JOTCSA. 2021;8(4):1251-62.

DOI: https://doi.org/10.18596/jotcsa.997521.

*Corresponding author. E-mail: eyup.yildirir@usak.edu.tr, Tel: +90 276221 2121/2768.

\section{INTRODUCTION}

Treating wastewater for reusing is vital for a sustainable future as fresh water resources are depleting due to rapid growth of population, pollution of water bodies, and drought due to global warming. Especially the textile industry produces a vast amount of wastewater as around $150 \mathrm{~L}$ of fresh water per $\mathrm{kg}$ of textile product is necessary and hence, great amount of wastewater containing many hazardous and toxic substances such as dye effluents is discharged during the process (1). Dyes in textile industry are synthetic organic materials with complex structure and they are nonbiodegradable (2). In addition, dyes containing $\mathrm{N}=\mathrm{N}-$ azo group (azo dyes) are considered toxic and carcinogenic and may create serious effects on organisms in the water bodies and human health
(3). There is a great variety in treatment of dye effluents in wastewater such as extraction via solvent, separation via membrane, advanced oxidation process, photodegradation, and adsorption (4-6). All these treatment processes have several advantages and disadvantages, while adsorption is a widely used technique due to its easy applicability, feasibility, and low cost.

The main drawback of adsorption process is the long residence times, however, application of ultrasound overcomes this situation and shortens the time required to reach equilibrium (7). In addition, its simplicity, low cost, satisfactory energy efficiency, and being environmentally friendly promotes its utilization (8). Ultrasound creates acoustic cavitation and the formed bubbles start to collide and create high temperature and pressure zones locally. Also, 
the shock waves promote the microscopic turbulence within the interfacial films surrounding the adsorbent's surface and increase the mass transfer, yielding a rapid adsorption and shorter residence time. During the collapse of the bubbles, micro-jets of solvent are formed perpendicular to the adsorbents surface and due their high speed, corrosion and erosion of the surface occurs $(7,9,10)$. As a result, without requiring a chemical additive and with a suitable adsorbent, ultrasound adsorption can be proper to remove dye effluents from the wastewater.

There are many studies in the literature showing that by using active carbon as adsorbent, many type of dye effluents can be cleaned $(11,12)$. The recent efforts to enhance the ultrasound adsorption is to utilize a low cost, stable adsorbent as active carbon is too expensive for the process. Vermicompost as soil amendment has unique properties such as high surface area with high porosity, high density of negative charges, low cost and functional groups within its structure. These properties make vermicompost a good adsorbent especially during the adsorption of metals, dye effluents and organic pollutants (13-16). However, there is not any report showing its applicability for dye adsorption from the wastewater in ultrasound media. In this work, Eriochrome Black T (EBT) as an azo-dye sample was subjected to adsorption via vermicompost in ultrasound media. The influences of $\mathrm{pH}$, adsorbent amount, operating time and initial EBT concentration on the adsorption capacity were examined. In addition, kinetic models (the first and second order pseudo and intraparticular models) and isotherm models (Langmuir, Freundlich, and Temkin) were utilized to determine their applicability with the experimental data.

\section{MATERIALS AND METHODS}

\section{Materials}

All chemicals were purchased from Sigma Aldrich. Bidistilled water was used in the all ultrasonicassisted adsorption experiments. VC was purchased from a local producer from İzmir, Turkey and it was produced from various city markets' waste and MSW. Initially, vermicompost was dried and sieved to yield a particle size of $0.125<\mathrm{Dp}<0.600$ [mm] for homogenization of the sample. Vermicompost had $31.05 \%$ ash content. The details of ash content determination method were given in our previous work (5).

\section{Ultrasonic-Assisted Adsorption}

The batch experimental set-up consisted of an ultrasonic homogenizer (Sonoplus HD 2200.2), operating at $200 \mathrm{~W}$ (nominal output) with a $13 \mathrm{~mm}$ titanium probe. $50 \mathrm{~mL}$ of conical centrifuge tubes were filled with $30 \mathrm{~mL}$ of EBT solutions comprising of different pHs. In ultrasonic-assisted adsorption experiments, $0.1 \mathrm{~g}$ of vermicompost was fed into a falcon tube. The amplitude of ultrasonic homogenizer was adjusted as $70 \%$. After the ultrasonic adsorption process completed within the designated time, the solution in the tube was syringed and centrifuged at $5000 \mathrm{rpm}$ for 1 minute. By using a UV-Vis spectrophotometer (Perkin Elmer, Lambda 365) at $\lambda \max (508 \mathrm{~nm})$ for $\mathrm{pH} 2$ the first and the final concentrations of EBT were determined. Adsorption capacity and removal percentage of EBT were calculated according to the Equations 1 and 2, respectively.

$$
\begin{aligned}
& q_{e}=\frac{\left(C_{0}-C_{e}\right) * V}{W} \\
& R \%=\frac{\left(C_{0}-C_{e}\right)}{C_{0}} \times 100
\end{aligned}
$$

$\mathrm{C}_{\mathrm{o}}$ and $\mathrm{C}_{\mathrm{e}}$ represent the initial and equilibrium concentration of the solution $\left(\mathrm{mgL}^{-1}\right)$, and $\mathrm{W}$ denotes the weight of VC $(\mathrm{g})$.

\section{Characterization of Vermicompost}

The functionality, structural morphology and crystallinity tests of raw vermicompost were performed via Spectrum Two Fourier Transform Infrared (FTIR) Spectrometer, Scanning electron microscope with Energy Dispersive X-Ray spectroscopy (SEM-EDX) and X-Ray Diffraction (XRD) for characterization. Moreover, point of zero charged of VC was determined in our previously published paper (5).

\section{Batch Kinetic Study}

The kinetic study of ultrasonic-assisted adsorption was carried out using several kinetic models in order to define the ultrasonic-assisted adsorption rate and mechanism. The applied kinetic models used in this study were pseudo-first order (17), the pseudosecond-order (18), and intraparticular (19) as shown in Table 1 . The best suitable model was determined by the determination of coefficient $\left(R^{2}\right)$ of the kinetic models.

\section{Isotherm Models}

Four different initial concentrations of EBT were used for determination of three isotherm models. These models with their equations are summarized in Table 2. All isotherm experiments conducted with $\mathrm{pH} 2$ of EBT solutions with a sonication time of 2 minutes. The obtained models served to explain the relations between the adsorbate and adsorbent. 
Table 1: Applied kinetic models for EBT adsorption onto vermicompost.

\section{Model}

Pseudo First Order

Pseudo Second Order

Intraparticular

\section{Equation}

$$
\ln \left(q_{e}-q_{t}\right)=\ln q_{e}-k_{1} t
$$

$$
\begin{gathered}
\frac{t}{q_{t}}=\frac{1}{k_{2} q_{e}^{2}}+\frac{t}{q_{e}} \\
q_{t}=K t^{0.5}+C
\end{gathered}
$$

$\mathrm{q}_{\mathrm{t}}=$ Adsorption capacity at any time $\left(\mathrm{mg} \mathrm{g}^{-1}\right) . \mathrm{k}_{1}=$ pseudo-first order rate constant $\left(\mathrm{min}^{-1}\right) ; \mathrm{k}_{2}=$ second-order pseudo rate constant $\left(\mathrm{g} \mathrm{mg}^{-1} \mathrm{~min}^{-1}\right), \mathrm{K}=$ intraparticular kinetic model constant $\left(\mathrm{mg} \mathrm{g}^{-1} \mathrm{~min}^{-0.5}\right)$ and $\mathrm{C}=\mathrm{y}$

\begin{tabular}{|c|c|c|c|}
\hline Models & Equations & Units & Ref. \\
\hline Langmuir & $\frac{C_{e}}{q_{e}}=\frac{1}{q_{\max } K_{L}}+\frac{C_{e}}{q_{\max }}$ & $\begin{array}{l}\text { qe: adsorbed amount }\left(\mathrm{mgg}^{-1}\right) \\
\mathrm{Ce}_{\mathrm{e}} \text { : adsorbed equilibrium } \\
\quad\left(\mathrm{mgL}^{-1}\right) \\
\mathrm{K}_{\mathrm{L}: \text { Langmuir constant related }} \\
\text { to sorption energy }\left(\mathrm{Lmg}^{-1}\right) \\
\text { qmax: maximum adsorption } \\
\text { capacity }\left(\mathrm{mgg}^{-1}\right) \text { related to } \\
\text { monolayer coverage }\end{array}$ & (20) \\
\hline Freundlich & $\ln q_{e}=\ln K_{F}+\frac{1}{n \ln C_{e}}$ & $\begin{array}{c}\begin{array}{c}\mathrm{C}_{\mathrm{e}} \text { : adsorbed equilibrium } \\
\left(\mathrm{mgL}^{-1}\right)\end{array} \\
\mathrm{K}_{\mathrm{F}}: \begin{array}{l}\text { Freundlich constant } \\
\left(\mathrm{mgg}^{-1}\right)\left(\mathrm{Lmg}^{-1}\right)^{\mathrm{n}}\end{array} \\
1 / \mathrm{n} \text { : intensity of adsorption }\end{array}$ & $(21)$ \\
\hline Temkin & $\begin{array}{c}q_{e}=B \ln a_{T}+B \ln C_{e} \\
B=\frac{R T}{b_{T}}\end{array}$ & $\begin{array}{l}\text { Ce: adsorbed equilibrium } \\
\left(\mathrm{mgL}^{-1}\right)\end{array}$ & (22) \\
\hline
\end{tabular}
intercept.

Table 2: Applied Isotherm Models with their equations and units.

\section{RESULTS AND DISCUSSION}

\section{Effect of pH of EBT Solutions on Adsorption Capacity}

Around $200 \mathrm{mgL}^{-1}$ of initial concentrations of EBT with different $\mathrm{pHs}(2-12)$ were prepared in order to predict the impact of pHs of adsorbate solution on the adsorption capacity. The ultrasonic-assisted adsorption experiments were performed with $70 \%$ amplitude during one minute. Figure 1 represents the effect of $\mathrm{pH}$ on the adsorption capacity. The highest adsorption capacity was obtained as 50.64 ( $\mathrm{mg}$-EBT $\left.\mathrm{g}^{-1}-\mathrm{VC}\right)$ at the $\mathrm{pH}$ of value of 2 . The minimum adsorption capacity $\left(4.22 \mathrm{mg}^{-E B T ~} \mathrm{~g}^{-1}-\mathrm{VC}\right)$ was observed at $\mathrm{pH} 12$. After determining the best $\mathrm{pH}$ of solution as $\mathrm{pH} \mathrm{2,} \mathrm{all} \mathrm{ultrasonic-assisted}$ adsorption experiments were carried out at a $\mathrm{pH}$ value of 2 .

The positive charge of $\mathrm{VC}$ was found as 8.51 in our previously published paper (5). The surface charge of $\mathrm{VC}$ has positive at $\mathrm{pH}<8.51$. The electrostatic attraction was occurred between the protonation of VC and the negatively charged EBT. While the $\mathrm{pH}$ increasing, VC has negatively charged and the repulsion dominated the VC and EBT interaction. Khan et al. (23) and Akhouairi et al. (24) mentioned similar findings in their studies. Moreover, Sriram et al. reported that UV-Vis spectrum of EBT solution was affected by $\mathrm{pH}(25)$. Between the $\mathrm{pH} 6$ and 10, dark blue color was gained and therefore, the wavelength of EBT's was shifted to $614 \mathrm{~nm}$ (25). 


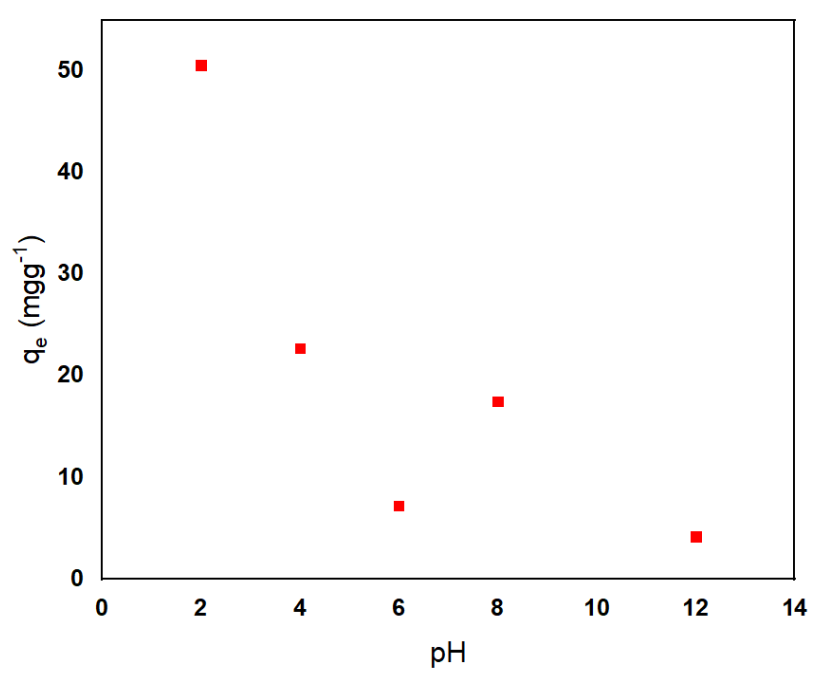

Figure 1: The effect of $\mathrm{pH}$ on the adsorption of EBT onto VC.

\section{Effect of the Adsorbent Amount on the Adsorption Capacity}

$85 \mathrm{mgL}^{-1}$ of EBT solution was prepared at optimal $\mathrm{pH}$ (2) for batch adsorption. Four levels of adsorbent doses (0.1-1 g) on adsorption capacity were evaluated. Figure 2 represents the various adsorbent doses versus adsorption uptake of EBT onto vermicompost. The value of $23.19 \mathrm{mg} \mathrm{g}^{-1}$ for EBT uptake on vermicompost found as the maximum adsorption capacity in the adsorbent dose range studied (Figure 2). Therefore, $0.1 \mathrm{~g}$ of vermicompost was used for the further evaluation.

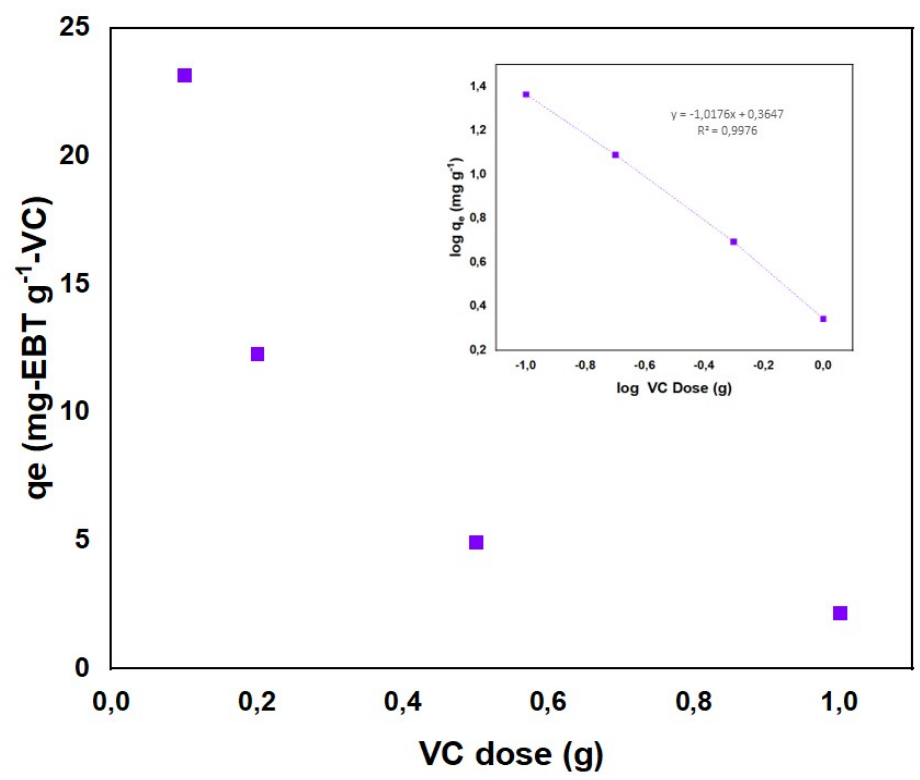

Figure 2: The effect of the amount of VC on the adsorption uptake of EBT onto VC.

Increasing adsorption dose leads to the logarithmic decrease on adsorption uptake of EBT onto adsorbent. Similar trend was observed by Bayomie et al. who investigated the methylene blue removal using fava bean peels utilizing ultrasonic-assisted method (26). They attributed the result to aggregation of adsorbent due to high amount of adsorbent and yielding a decrease in the surface area due to the overlapping of the functional vacant sites.

\section{Effect of Operation Time}

In order to investigate the effect of ultrasonication time on adsorption capacity of vermicompost, ultrasonic assisted adsorption carried out by using $0.1 \mathrm{~g}$ of $\mathrm{VC}$ and $130 \mathrm{mg} \mathrm{L}^{-1}$ of initial EBT solution concentration at $\mathrm{pH} 2$. Figure 3 represents that optimum ultrasound duration was found to be 120 seconds. The obtained maximum adsorption capacity of EBT onto VC was determined as 31.83 $\mathrm{mg}-\mathrm{EBT} / \mathrm{g}^{-1}$ adsorbent. In addition, it can be said 
that $83.3 \%$ of maximum adsorption capacity was reached within $60 \mathrm{sec}$. Isotherm studies were performed with a ultrasonication time of $120 \mathrm{sec}$ according to the determined optimal conditions. A rapid adsorption was appeared owing to the ultrasonic-assisted adsorption via cavitation phenomena. These findings have similar trends with the results of Roosta et al. (27) who studied malachite green removal by using ultrasound effect. It can be interpreted that a highly fast adsorption occurred owing to the dispersion of adsorption by the ultrasonic cavitation.

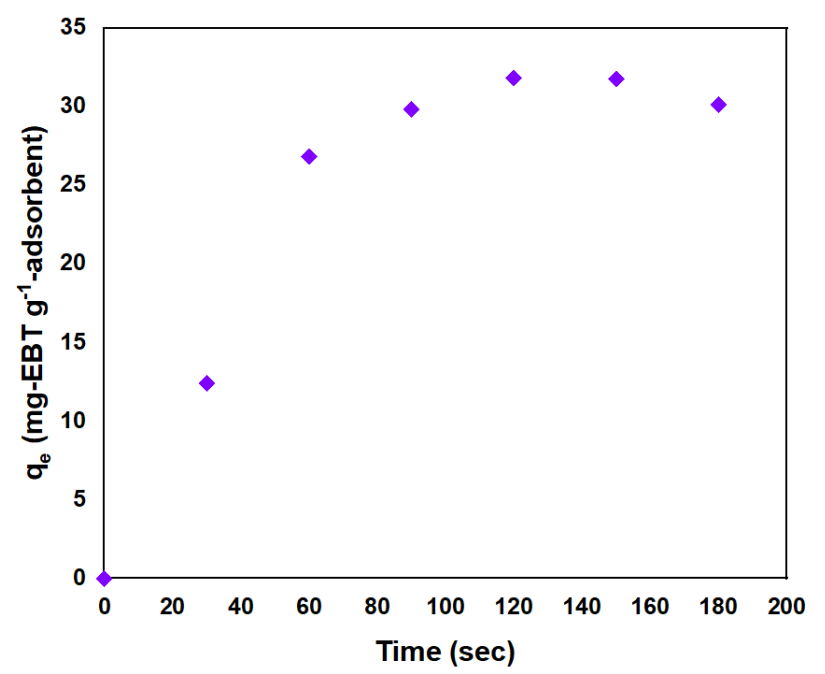

Figure 3: The effect of ultrasonic duration on the adsorption uptake of EBT onto VC.

\section{Effect of initial EBT concentration}

To assess the impact of numerous initial concentrations of EBT $\left(122-494 \mathrm{mg} \mathrm{L}^{-1}\right)$ on adsorption uptake of EBT onto VC was applied. The increase of the sorption uptake onto VC was from 31 to $139 \mathrm{mg} \mathrm{g}^{-1}$, when initial concentration of EBT were varied from $122 \mathrm{mgL}^{-1}$ to $494 \mathrm{mgL}^{-1}$ (Figure 4). An increase of the EBT concentration could be resulted in the increase of driving force concentration and this leaded to a situation that mass transport occurred very fast from the solute to the surface of VC (11). Besides, it is well known that sonication helps to the improvement of mass transfer. Accordingly, the micro-jets occurred owing to the ultrasound and hence, the increase of the mass transfer was observed (27).

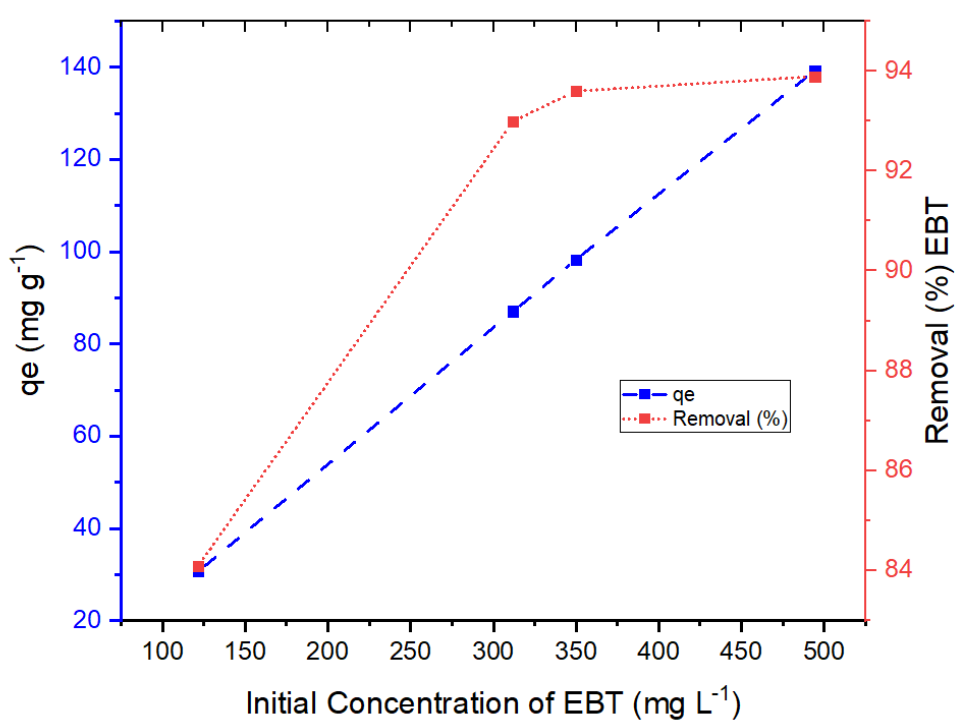

Figure 4: The effect of EBT's initial concentration on the adsorption uptake of EBT onto VC.

\section{Kinetic Study of EBT Sorption onto VC}

Table 3 presents the relevant values of sorption rate constants and determination coefficients of the applied kinetic models. The highest $\mathrm{R}^{2}$ value was found to be 0.9824 for pseudo-first order. This value indicated that a good correlation occurred between the model and the results of the experimental findings. Furthermore, $\mathrm{R}^{2}$ value of 0.9580 was 
obtained for intraparticle-diffusion model. According to Figure 5, there are two linear regions on the plot of intraparticular model. While the first line shows EBT dye ions transport to VC's external surface, the second line implies that the intraparticle diffusion was occurred through the macropores (28). All of the graphs of kinetic models are represented in Figures 5 a-c.

Table 3: Applied kinetic models' parameters for EBT adsorption onto VC at $298 \mathrm{~K}$.

\begin{tabular}{ccc}
\hline Models & Parameters & Value \\
\hline Pseudo-first order & $\mathrm{q}_{\mathrm{e}}$ & 36.02 \\
& $\mathrm{k}_{1}$ & 0.03 \\
& $\mathrm{R}^{2}$ & 0.9824 \\
\hline Pseudo-second & $\mathrm{q}_{\mathrm{e}}$ & 36.90 \\
order & $\mathrm{k}_{2}$ & 0.0011 \\
& $\mathrm{R}^{2}$ & 0.8304 \\
\hline Intraparticular & $\mathrm{K}_{\mathrm{d}}$ & 3.11 \\
Diffusion & $\mathrm{C}$ & -0.759 \\
& $\mathrm{R}^{2}$ & 0.9580 \\
\hline
\end{tabular}

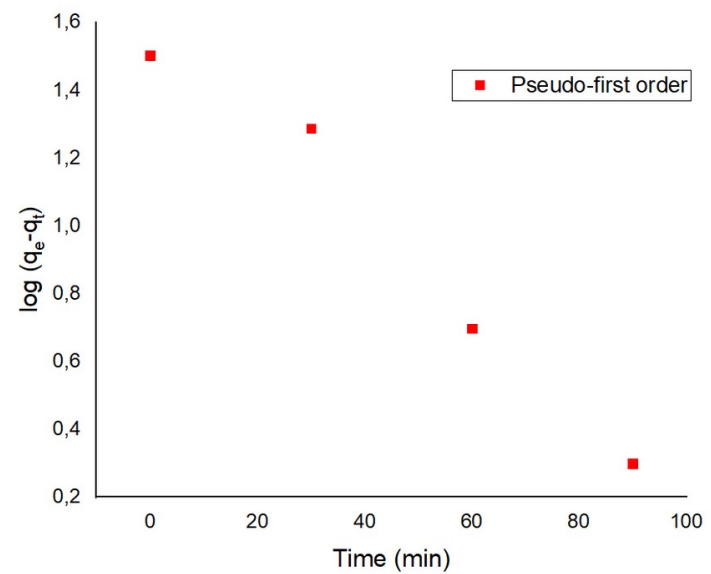

(a)

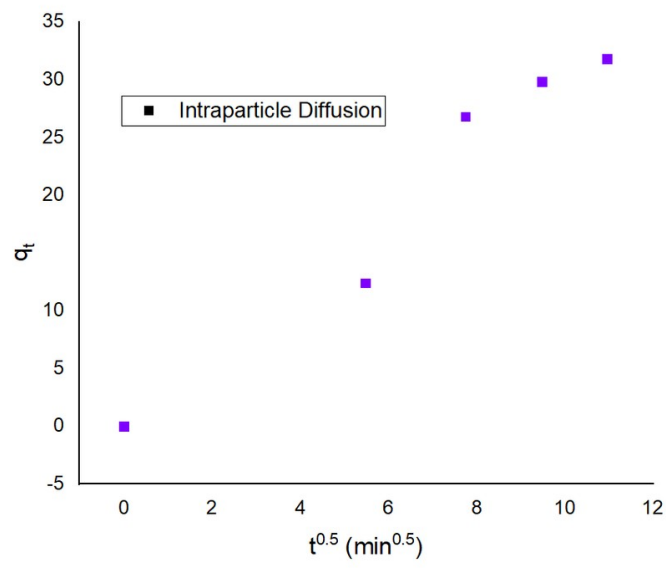

(b)

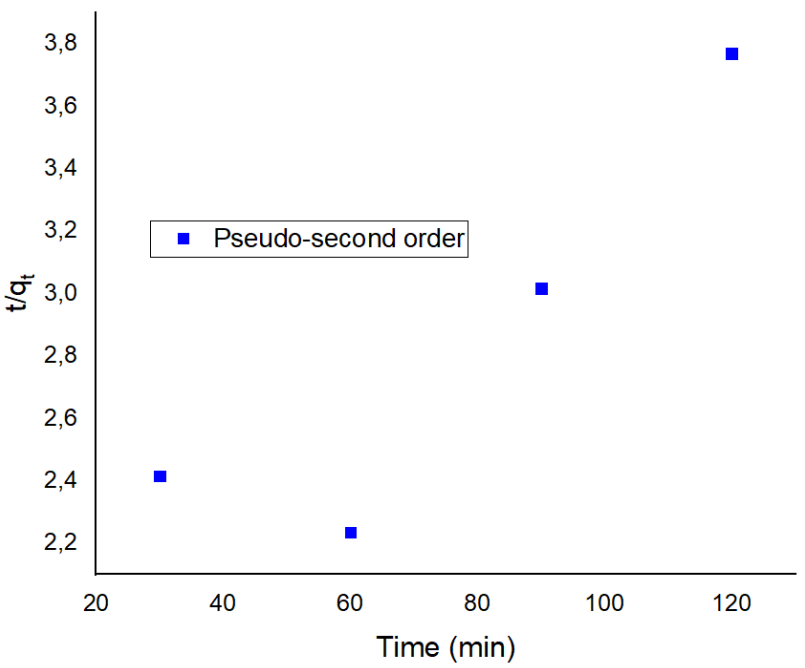

(c)

Figure 5: Modelling kinetics of EBT adsorption onto the VC a) pseudo-first-order b) pseudo- second-order, c) intraparticle diffusion.

\section{Modelling Isotherms of EBT Sorption onto VC}

The independent variables of isotherm models are shown in Table 4. The determination coefficients of both Langmuir and Temkin isotherm models were 0.87 and 0.8659, respectively. However, the determination coefficient of Freundlich isotherm was obtained as 0.6941. The Freundlich isotherm indicates that a monolayer adsorption onto VC occurred. There was no lateral interactions between the VC and adsorbed EBT dye ions (29). 
Furthermore, Temkin isotherm model's parameters suggest that the ultrasonic-assisted EBT adsorption onto VC was exothermic since Bt value was determined as a positive value and the interaction between the adsorbent and adsorbate was physisorption (30).

Table 4: Applied isotherm models' parameters for EBT adsorption onto VC at $298 \mathrm{~K}$.

\begin{tabular}{ccc}
\hline Models & Parameters & Value \\
\hline \multirow{4}{*}{ Langmuir } & $\mathrm{q}_{\mathrm{e}, \mathrm{c}}$ (calculated) & 36.02 \\
& $\mathrm{q}_{\mathrm{m}}$ (max) & -36.64 \\
& $\mathrm{~K}_{\mathrm{L}}$ & -0.029 \\
& $\mathrm{R}^{2}$ & 0.87 \\
\hline \multirow{3}{*}{ Freundlich } & $\mathrm{q}_{\mathrm{e}}$ & 36.90 \\
& $\mathrm{k}_{2}$ & 0.0097 \\
& $\mathrm{R}^{2}$ & 0.6941 \\
& $\mathrm{n}$ & 0.3493 \\
\hline \multirow{2}{*}{ Temkin } & $\mathrm{K}_{\mathrm{t}}$ & 5.4735 \\
& $\mathrm{~B}_{\mathrm{t}}$ & 219.84 \\
& $\mathrm{R}^{2}$ & 0.8659 \\
\hline
\end{tabular}

\section{Characterization of VC}

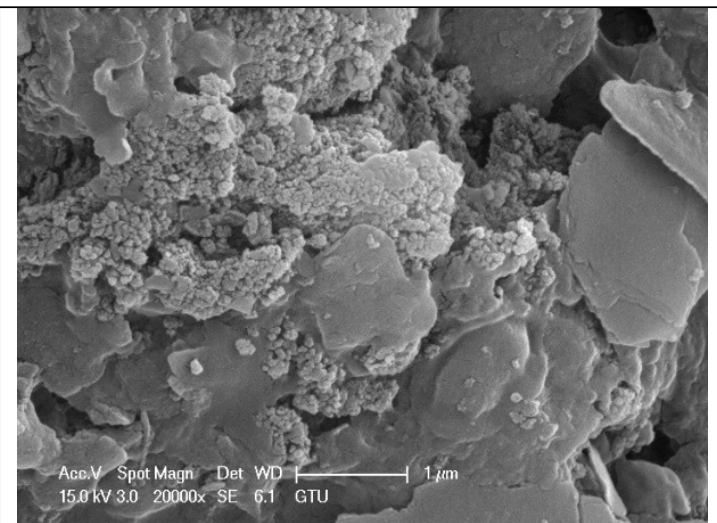

a)

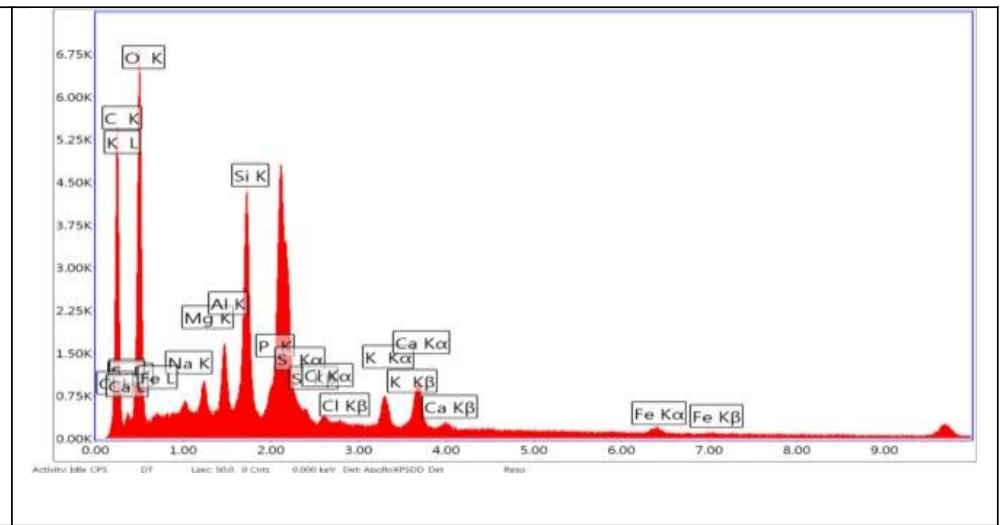

b)

Figure 6: a) SEM image of raw VC at a scale of $1 \mu \mathrm{m}$, (b) EDS of raw VC.

Vermicompost has gained attention to be used as an adsorbent for disposal of organic and inorganic contaminants in the water and studies showed that due to functional groups existing naturally, made vermicompost an effective adsorbent (31). The flakes and fragments were shown in the micrograph of raw vermicompost (Figure $6 \mathrm{a}$ ). This phenomenon may be explained owing to the organic and inorganic content of the vermicompost's structure. In fact, enzyme and numerous bacteria stick to the substrate until they get to the earthworm's gut $(32,33)$. Hence, the degree of degradation of them was reflected by the image of SEM. EDX spectrum (Figure 6b) reveals that various metals exist in its structure.

The FTIR spectrum of raw vermicompost is shown in Figure 7. The very broad peak between the wavenumbers of 3700 and $3000 \mathrm{~cm}^{-1}$ represents the hydroxyl $(-\mathrm{OH})$ functional group in carboxylic acids as well as alcohols and phenols. In addition, the broad peak also overlaps the $\mathrm{C}-\mathrm{H}$ peak observed around $2900 \mathrm{~cm}^{-1}$, which is typical for carboxylic acids (13). Vermicompost consists of organic and inorganic fractions and humic substances which are of carboxylic acid nature, are comprising the majority of the organic constituents (34). The sharp peak at $1630 \mathrm{~cm}^{-1}$ indicates the existence of amides as it might belong to stretching $-\mathrm{C}=\mathrm{O}$ bands (31). While the small peak at $1490 \mathrm{~cm}^{-1}$ can be attributed to $\mathrm{C}=\mathrm{C}$, the peak at $1420 \mathrm{~cm}^{-1}$ shows the $\mathrm{CO}_{3}{ }^{2-}$ groups (14). Stretching $\mathrm{O}-\mathrm{C}$ bands are observed at $1030 \mathrm{~cm}^{-1}$ which might represent carboxylic acids (2).

After the adsorption of EBT, the broad peak representing $-\mathrm{OH}$ almost flattened suggesting that hydroxyl groups on the surface of vermicompost involved in the adsorption. In addition, the magnitude of the peaks at 1630, 1420 and 1030 $\mathrm{cm}^{-1}$ lowered indicating that EBT dye molecules attached to the functional groups of $-\mathrm{C}=\mathrm{O}$ and $\mathrm{O}-\mathrm{C}$ on the surface of vermicompost (35).

XRD pattern of vermicompost was shown in Figure 8. The peaks at 21.70 and 26.64 were attributed to quartz $\left(\mathrm{SiO}_{2}\right)$. The other low intensity peak appeared at 27.91 owing to the existence of sylvite (36). The sharp two peaks emerged at 54.86 and 69.24 corresponding to kotoite (37). 


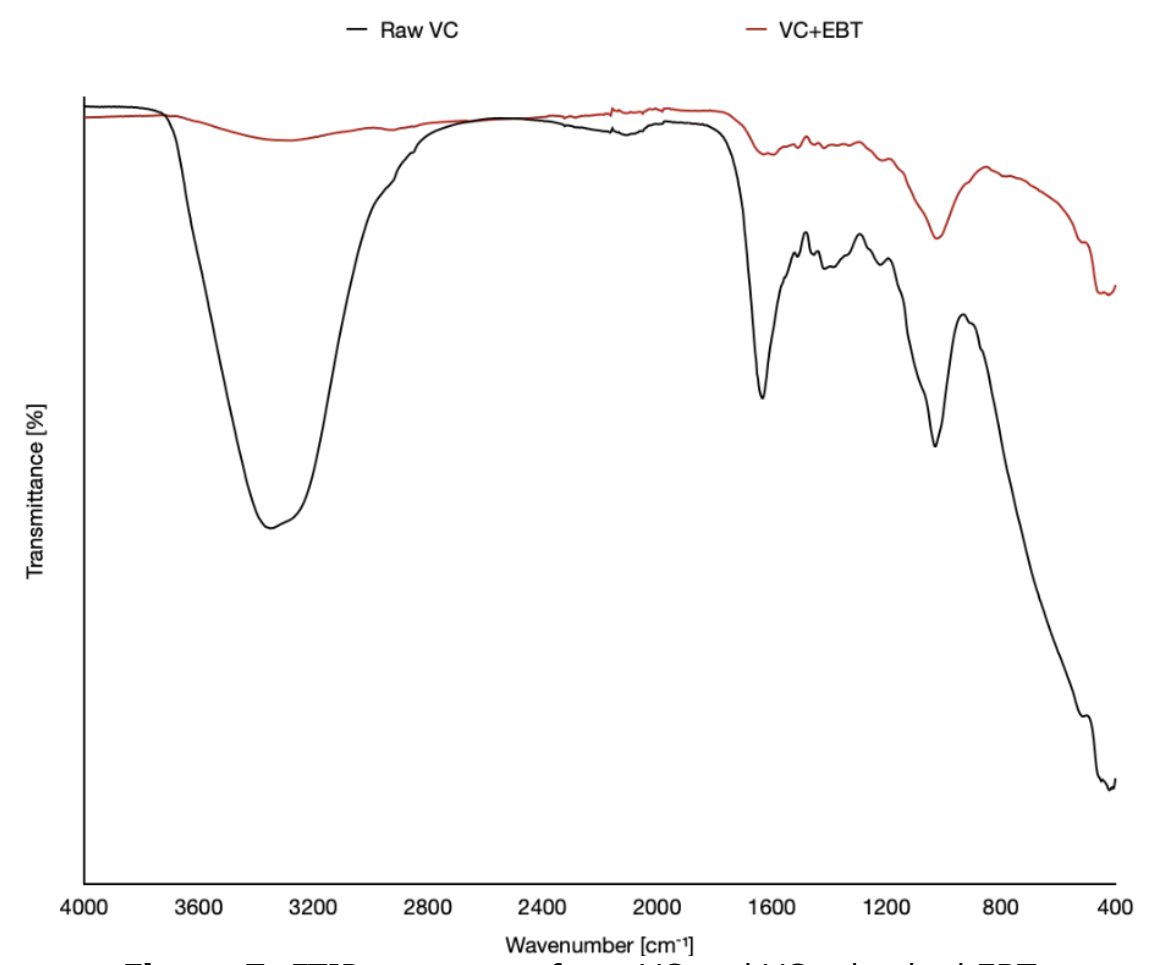

Figure 7: FTIR spectrum of raw VC and VC-adsorbed EBT.

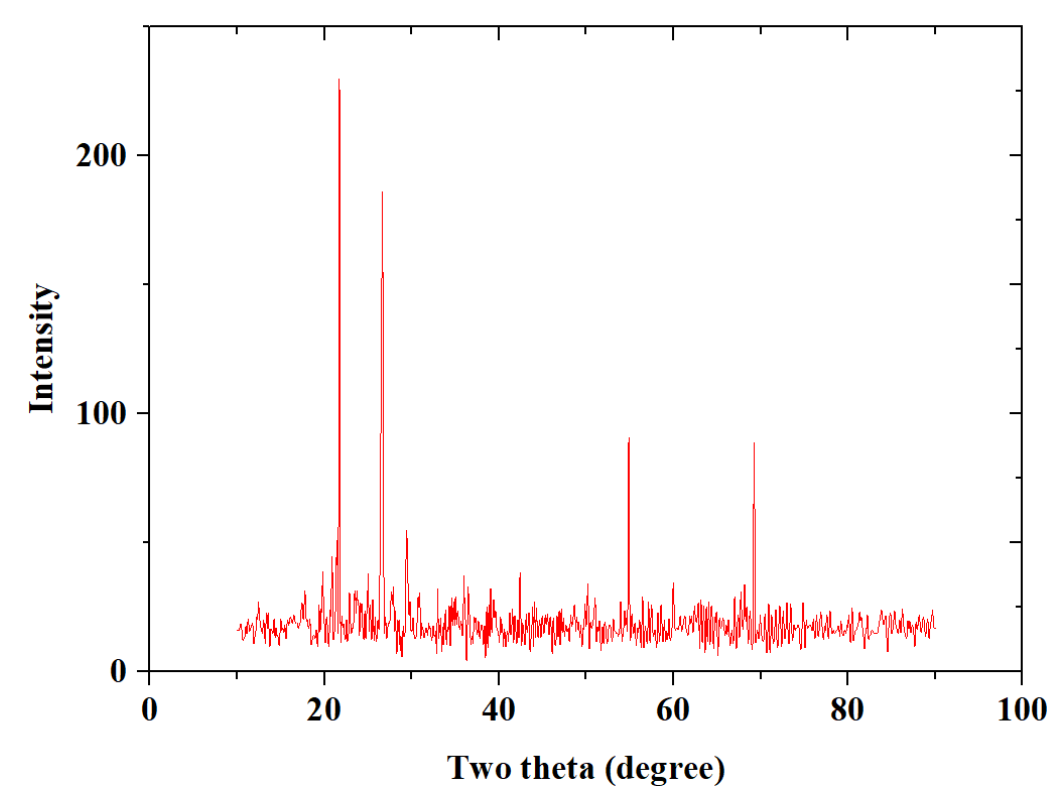

Figure 8: X-ray diffraction (XRD) pattern of raw VC.

Comparison of Different Adsorbents for the Removal of EBT

Table 5 displays the summary of literature for adsorbents for EBT removal. The adsorbents were prepared in many steps including microwave, impregnation, pyrolysis methods which are timeconsuming and bring economic burden to the adsorption process. Thus, it can be said that VC as adsorbent is cost-effective. Besides, ultrasonicationadsorption process gave better results in a short time containing less solvent. As a result, these advantages make ultrasonic assisted adsorption of EBT onto VC as a promising method. 
Table 5: Comparison of adsorbents for EBT adsorption.

\begin{tabular}{|c|c|c|}
\hline Adsorbents & $\begin{array}{l}\text { Maximum } \\
\text { adsorption } \\
\text { capacity }\left(\mathrm{mg} \mathrm{g}^{-1}\right)\end{array}$ & Ref. \\
\hline $\begin{array}{l}\text { Almond Shell with Microwave } \\
\text { radiation } \\
\text { Almond Shell with cold } \\
\text { Almond Shell (untreated) }\end{array}$ & $\begin{array}{l}29.41 \\
18.18 \\
6.06\end{array}$ & (38) \\
\hline Peanut shell & 40.81 & (39) \\
\hline $\begin{array}{l}\text { Hydrophobic cross-linked } \\
\text { polyzwitterionic acid }\end{array}$ & 15.9 & $(40)$ \\
\hline $\mathrm{MoNiO}_{4}$ & 6.66 & $(41)$ \\
\hline $\begin{array}{l}\text { Alginate/basil seed mucilage } \\
\text { biocomposite }\end{array}$ & 2.80 & $(42)$ \\
\hline $\begin{array}{l}\text { Alrhaji Steel slag } \\
\text { Arabian Steel slag }\end{array}$ & $\begin{array}{l}25.88-34.82 \\
34.93-39.69\end{array}$ & $(43)$ \\
\hline $\mathrm{HCl}$ activated Nteje Clay & 24.04 & $(44)$ \\
\hline $\begin{array}{l}\text { Bare ZnO } \\
\text { CTAB@ZnO } \\
\text { BMTF@ZnO }\end{array}$ & $\begin{array}{l}32.56 \\
56.82 \\
78.34\end{array}$ & $(45)$ \\
\hline Raw Montmorillonite & 99.0 & $(46)$ \\
\hline Raw VC & 50.64 & $\begin{array}{l}\text { This } \\
\text { study }\end{array}$ \\
\hline
\end{tabular}

\section{CONCLUSION}

The current study indicated that VC could be an economical sorbent for EBT elimination from aqueous media. The ultrasonic-assisted adsorption as one of the novel enhanced adsorption methods was preferred since the removal of EBT from aqueous media was high, owing to the microjet effects. Various independent factors were selected such as $\mathrm{pH}, \mathrm{VC}$ dose, initial concentration of EBT. The adsorption efficiency was highly affected with the changing $\mathrm{pH}$ value. The vital $\mathrm{pH}$ of this process was determined as 2 . The determination coefficient of Temkin isotherm model $\left(R^{2}=0.8659\right)$ revealed that suggested model was compatible to experimental results. The applied kinetic data revealed that the pseudo-first order kinetic model is well-fitted to ultrasonic-assisted data with high coefficient of determination $\left(R^{2}=0.9824\right)$. Furthermore, ultrasonic-assisted adsorption was so rapid that this technique could reduce the time required hence, providing better results compared to batch adsorption. Besides, EDX analysis revealed that VC has numerous organic and inorganic materials, thus flakes and segments were observed. Moreover, FTIR analyses explained well the adsorption behavior between the VC and EBT. XRD analysis enlighten the crystallographic structure of VC.

\section{REFERENCES}

1. Yin $H$, Qiu P, Qian $Y$, Kong Z, Zheng $X$, Tang Z, et al. Textile Wastewater Treatment for Water Reuse: A Case Study. Processes. 2019 Jan 11;7(1):34. $\leq \mathrm{DOI}>$.

2. de Luna MDG, Flores ED, Genuino DAD, Futalan
CM, Wan M-W. Adsorption of Eriochrome Black T (EBT) dye using activated carbon prepared from waste rice hulls-Optimization, isotherm and kinetic studies. Journal of the Taiwan Institute of Chemical Engineers. $2013 \mathrm{Jul} ; 44(4): 646-53$. <DOI $>$.

3. Paixão K, Abreu E, Lamas Samanamud GR, Boscaro França A, Almeida Loures CC, Prado Baston $\mathrm{E}$, et al. Normal boundary intersection applied in the scale-up for the treatment process of Eriochrome Black $\mathrm{T}$ through the UV/TiO2/O3 system. Journal of Environmental Chemical Engineering. 2019 Feb;7(1): 102801. <DOI>.

4. Khurana I, Shaw AK, Bharti, Khurana JM, Rai PK. Batch and dynamic adsorption of Eriochrome Black T from water on magnetic graphene oxide: Experimental and theoretical studies. Journal of Environmental Chemical Engineering. 2018 Feb;6(1):468-77. <DOI $>$.

5. İlbay Z, Yildirir E. Vermicompost as a potential adsorbent for the adsorption of methyleneblue dye from aqueous soulutions. Journal of the Turkish Chemical Society Section A: Chemistry. 2020 Oct 23;893-902. <DOI $>$.

6. Crini G. Non-conventional low-cost adsorbents for dye removal: A review. Bioresource Technology. 2006 Jun;97(9):1061-85. <DOI>.

7. Ismail BB, Yusuf $\mathrm{HL}$, Pu Y, Zhao H, Guo M, Liu D. Ultrasound-assisted adsorption/desorption for the enrichment and purification of flavonoids from baobab (Adansonia digitata) fruit pulp. Ultrasonics Sonochemistry. 2020 Jul;65:104980. <DOI>.

8. Ismail BB, Guo M, Pu Y, Wang W, Ye X, Liu D. 
Valorisation of baobab (Adansonia digitata) seeds by ultrasound assisted extraction of polyphenolics. Optimisation and comparison with conventional methods. Ultrasonics Sonochemistry. 2019 Apr;52:257-67. <DOI $>$.

9. Thompson LH, Doraiswamy LK. Sonochemistry: Science and Engineering. Ind Eng Chem Res. 1999 Apr $1 ; 38(4): 1215-49$. <DOI>.

10. Pankaj, Sharma R, Verma SK. Equilibrium, kinetic and mechanism studies on adsorption of textile disperse dye from aqueous solution onto $\mathrm{TiO} 2$ in the presence of ultrasound and rare earth ions. Materials Today: Proceedings. 2021;44:215867. $\leq \mathrm{DOI}>$.

11. Hamdaoui $O$, Chiha M, Naffrechoux E. Ultrasound-assisted removal of malachite green from aqueous solution by dead pine needles. Ultrasonics Sonochemistry. 2008 Jul;15(5):799807. $\leq \mathrm{DOI}>$.

12. Hamdaoui O, Naffrechoux E, Tifouti L, Pétrier C. Effects of ultrasound on adsorption-desorption of $p$ chlorophenol on granular activated carbon. Ultrasonics Sonochemistry. 2003 Mar;10(2):10914. $\leq \mathrm{DOI}>$.

13. Yang G, Wang Z, Xian Q, Shen F, Sun C, Zhang $Y$, et al. Effects of pyrolysis temperature on the physicochemical properties of biochar derived from vermicompost and its potential use as an environmental amendment. RSC Adv. 2015;5(50):40117-25. <DOI>.

14. Zhou B, Wang Z, Shen D, Shen F, Wu C, Xiao R. Low cost earthworm manure-derived carbon material for the adsorption of $\mathrm{Cu} 2+$ from aqueous solution: Impact of pyrolysis temperature. Ecological Engineering. 2017 Jan;98:189-95. $\leq \mathrm{DOI}$.

15. Zhu W, Du $W$, Shen $X$, Zhang $H$, Ding $Y$. Comparative adsorption of $\mathrm{Pb} 2+$ and $\mathrm{Cd} 2+$ by cow manure and its vermicompost. Environmental Pollution. 2017 Aug;227:89-97. <DOI>.

16. Yang G, Wu L, Xian Q, Shen F, Wu J, Zhang Y. Removal of Congo Red and Methylene Blue from Aqueous Solutions by Vermicompost-Derived Biochars. Singer AC, editor. PLoS ONE. 2016 May 4;11(5):e0154562. <DOI>.

17. Lagergren S. About the Theory of So-called Adsorption of Soluble Substances. Kungliga Svenska Vetenskapsakademiens Handlingar. 1898;24:1-39.

18. Ho YS, McKay G. A Comparison of Chemisorption Kinetic Models Applied to Pollutant Removal on Various Sorbents. Process Safety and Environmental Protection. 1998 Nov;76(4):332-40. $\leq \mathrm{DOI}>$.

19. Weber WJ, Morris JC. Kinetics of Adsorption on Carbon from Solution. J Sanit Engrg Div. 1963 Apr;89(2):31-59. <DOI>.

20. Langmuir I. The adsorption of gases on plane surfaces of glass, mica and platinum. J Am Chem Soc. 1918 Sep;40(9):1361-403. <DOI>.

21. Freundlich $H$. Über die Adsorption in Lösungen. Zeitschrift für Physikalische Chemie. 1907 Oct $1 ; 57 \mathrm{U}(1): 385-470$. $\leq \mathrm{DOI}>$.

22. Temkin M. Kinetics of ammonia synthesis on promoted iron catalysts. Acta physiochim URSS. $1940 ; 12: 327-56$.

23. Khan A, Wang $X$, Gul K, Khuda F, Aly Z, Elseman AM. Microwave-assisted spent black tea leaves as cost-effective and powerful green adsorbent for the efficient removal of Eriochrome black $\mathrm{T}$ from aqueous solutions. Egyptian Journal of Basic and Applied Sciences. 2018 Jun;5(2):171-82. $\leq$ DOI $>$.

24. Akhouairi S, Ouachtak $H$, Addi AA, Jada A, Douch J. Natural Sawdust as Adsorbent for the Eriochrome Black T Dye Removal from Aqueous Solution. Water Air Soil Pollut. 2019 Aug;230(8):181. <DOI>.

25. Sriram G, Uthappa UT, Rego RM, Kigga M, Kumeria $\mathrm{T}$, Jung $\mathrm{H}-\mathrm{Y}$, et al. Ceria decorated porous diatom-xerogel as an effective adsorbent for the efficient removal of Eriochrome Black T. Chemosphere. 2020 Jan;238:124692. <DOI>.

26. Bayomie OS, Kandeel $H$, Shoeib $T$, Yang $H$, Youssef N, El-Sayed MMH. Novel approach for effective removal of methylene blue dye from water using fava bean peel waste. Sci Rep. 2020 Dec;10(1): 7824. <DOI>.

27. Roosta M, Ghaedi M, Shokri N, Daneshfar A, Sahraei R, Asghari A. Optimization of the combined ultrasonic assisted/adsorption method for the removal of malachite green by gold nanoparticles loaded on activated carbon: Experimental design. Spectrochimica Acta Part A: Molecular and Biomolecular Spectroscopy. 2014 Jan;118:55-65. $\leq$ DOI $>$.

28. Asfaram A, Ghaedi M, Hajati S, Goudarzi A. Ternary dye adsorption onto MnO 2 nanoparticleloaded activated carbon: derivative spectrophotometry and modeling. RSC Adv. 2015;5(88):72300-20. <DOI>.

29. Shikuku VO, Mishra T. Adsorption isotherm modeling for methylene blue removal onto magnetic kaolinite clay: a comparison of two-parameter 
isotherms. Appl Water Sci. 2021 Jun;11(6):103. $\leq$ DOI $>$.

30. Rahangdale D, Kumar A. Chitosan as a substrate for simultaneous surface imprinting of salicylic acid and cadmium. Carbohydrate Polymers. 2018 Dec;202:334-44. <DOI>.

31. Pereira MG, Arruda MAZ. Vermicompost as a natural adsorbent material: characterization and potentialities for cadmium adsorption. J Braz Chem Soc. 2003 Jan; 14(1):39-47. <DOI $>$.

32. Hussain $\mathrm{N}$, Abbasi $\mathrm{T}$, Abbasi SA. Vermicomposting-mediated conversion of the toxic and allelopathic weed ipomoea into a potent fertilizer. Process Safety and Environmental Protection. 2016 Sep;103:97-106. <DOI $>$.

33. Ali U, Sajid N, Khalid A, Riaz L, Rabbani MM, Syed $\mathrm{JH}$, et al. A review on vermicomposting of organic wastes. Environ Prog Sustainable Energy. 2015 Jul 8;34(4):1050-62. <DOI $>$.

34. Manzar MS, Zubair M, Khan NA, Husain Khan A, Baig U, Aziz MA, et al. Adsorption behaviour of green coffee residues for decolourization of hazardous congo red and eriochrome black $\mathrm{T}$ dyes from aqueous solutions. International Journal of Environmental Analytical Chemistry. 2020 Aug $26 ; 1-17 . \leq \mathrm{DOI}>$.

35. Khalid A, Zubair M, Ihsanullah. A Comparative Study on the Adsorption of Eriochrome Black T Dye from Aqueous Solution on Graphene and AcidModified Graphene. Arab J Sci Eng. 2018 May;43(5):2167-79. $\leq$ DOI $>$.

36. Azargohar R, Nanda S, Kozinski JA, Dalai AK, Sutarto R. Effects of temperature on the physicochemical characteristics of fast pyrolysis biochars derived from Canadian waste biomass. Fuel. 2014 Jun;125:90-100. <DOI>.

37. Zhu F, Hou J, Xue S, Wu C, Wang Q, Hartley W. Vermicompost and Gypsum Amendments Improve Aggregate Formation in Bauxite Residue. Land Degrad Develop. 2017 Oct;28(7):2109-20. <DOI>.

38. Şahin Ö, Saka C, Kutluay S. Cold plasma and microwave radiation applications on almond shell surface and its effects on the adsorption of Eriochrome Black T. Journal of Industrial and Engineering Chemistry. 2013 Sep;19(5):1617-23. $\leq$ DOI .

39. Boumchita $S$, Lahrichi $A$, Benjelloun $Y$, Lairini $S$, Nenov V, Zerrouq F. Application of Peanut shell as a low-cost adsorbent for the removal of anionic dye from aqueous solutions. Journal of Materials and Environmental Science. 2017;8(7):2353-64.
40. Saleh TA, Musa AM, Ali SA. Synthesis of hydrophobic cross-linked polyzwitterionic acid for simultaneous sorption of Eriochrome black $T$ and chromium ions from binary hazardous waters. J Colloid Interface Sci. 2016 Apr 15;468:324-33. $<$ DOI $>$.

41. Salimi F, Valiei V, Karami C. Removal of EBT dye from aqueous solution by modified MoNiO4 adsorbent. Desalination Water Treat. 2020;190:340-52. <DOI $>$.

42. Javanbakht V, Shafiei R. Preparation and performance of alginate/basil seed mucilage biocomposite for removal of eriochrome black $T$ dye from aqueous solution. International Journal of Biological Macromolecules. 2020 Jun;152:9901001. <DOI $>$.

43. Manzar MS, Khan G, dos Santos Lins PV, Zubair M, Khan SU, Selvasembian R, et al. RSM-CCD optimization approach for the adsorptive removal of Eriochrome Black $T$ from aqueous system using steel slag-based adsorbent: Characterization, Isotherm, Kinetic modeling and thermodynamic analysis. Journal of Molecular Liquids. 2021 Oct;339:116714. <DOI $>$.

44. Onu CE, Nwabanne JT, Ohale PE, Asadu CO. Comparative analysis of RSM, ANN and ANFIS and the mechanistic modeling in eriochrome black-T dye adsorption using modified clay. South African Journal of Chemical Engineering. 2021 Apr;36:2442. $\leq \mathrm{DOI}>$.

45. Kaur $Y$, Jasrotia $T$, Kumar R, Chaudhary GR, Chaudhary $S$. Adsorptive removal of eriochrome black T (EBT) dye by using surface active low cost zinc oxide nanoparticles: A comparative overview. Chemosphere. 2021 Sep;278:130366. <DOI>.

46. Rashidi R, Omidi Khaniabadi $Y$, Ghaderpoori M. Adsorption of Eriochrome black- $T$ from aqueous environment by raw Montmorillonite. International Journal of Environmental Analytical Chemistry. 2021 Mar 8;1-15. <DOI $>$. 
